\title{
Improved synthesis of DQ-113, a new quinolone antibacterial agent, utilizing the Reformatsky reaction
}

\author{
Hiroaki Inagaki,* Kazuyuki Sugita, Rie N. Miyauchi, Satoru Miyauchi, Toshiyuki Takeda, \\ Masao Itoh, Hisashi Takahashi, and Makoto Takemura
}

Medicinal Chemistry Research Laboratory, Daiichi Pharmaceutical Co. Ltd., 16-13, Kita-Kasai 1-Chome, Edogawa-ku, Tokyo 134-8630, Japan.

E-mail:inagaeeb@daiichipharm.co.jp

\section{Dedicated to Professor Keiichiro Fukumoto on his $70^{\text {th }}$ birthday}

(received 25 May 03; accepted 24 July 03; published on the web 30 July 03)

\begin{abstract}
A new improved synthetic route for the C-7 substituent in DQ-113, a new quinolone antibacterial agent for infections caused by Gram-positive pathogens, has been developed which does not use low temperatures and avoids the use of expensive fluorinating agents. The key step is a Reformatsky reaction between ethyl bromofluoroacetate and ethyl 1-acetylcyclopropanecarboxylate.
\end{abstract}

Keywords: DQ-113, Reformatsky reaction

\section{Introduction}

DQ-113, which is 5-amino-7-[(3S,4R)-4-(1-aminocycloprop-1-yl)-3-fluoropyrrolidin-1-yl]-6fluoro-1-[(1R,2S)-2-fluorocycloprop-1-yl]-1,4-dihydro-8-methyl-4-oxoquinoline-3-carboxylic acid (7), is a new potent antibacterial agent for infections caused by Gram-positive pathogens including multi-drug resistant strains, and is currently undergoing preclinical evaluation by Daiichi. ${ }^{1,2}$ One of the structural features of DQ-113 is its possession of the cis-oriented $(3 S, 4 R)$ 4-(1-aminocycloprop-1-yl)-3-fluoropyrrolidine moiety as the C-7 substituent, which has been shown to be indispensable for its effective biological properties. ${ }^{1}$ Earlier we have reported a preparative synthetic method for the C-7 substituent: (3S,4R)-4-(1-tertbutoxycarbonylaminocycloprop-1-yl)-3-fluoropyrrolidine (6), which have as key steps the fluorination of ethyl 1-\{(3S)-5-oxo-1-[(S)-1-phenylethyl]pyrrolidin-3-yl $\}$ cyclopropanecarboxylate (4), using lithium diisopropylamide (LDA) and $N$-fluorobenzene-sulfonimide at $-78{ }^{\circ} \mathrm{C}$, followed by isomerization of the resultant trans-fluorinated pyrrolidine by using LDA and 2,6-di-tertbutylphenol at $-78{ }^{\circ} \mathrm{C}$ (Scheme 1). ${ }^{1}$ However, the key steps using LDA and expensive 
fluorinating agents at low temperature are not acceptable for large scale synthesis. To produce the intermediate 6 more efficiently than in the initial method, a new synthetic route has been designed and studied, which uses a Reformatsky reaction with ethyl bromofluoroacetate.

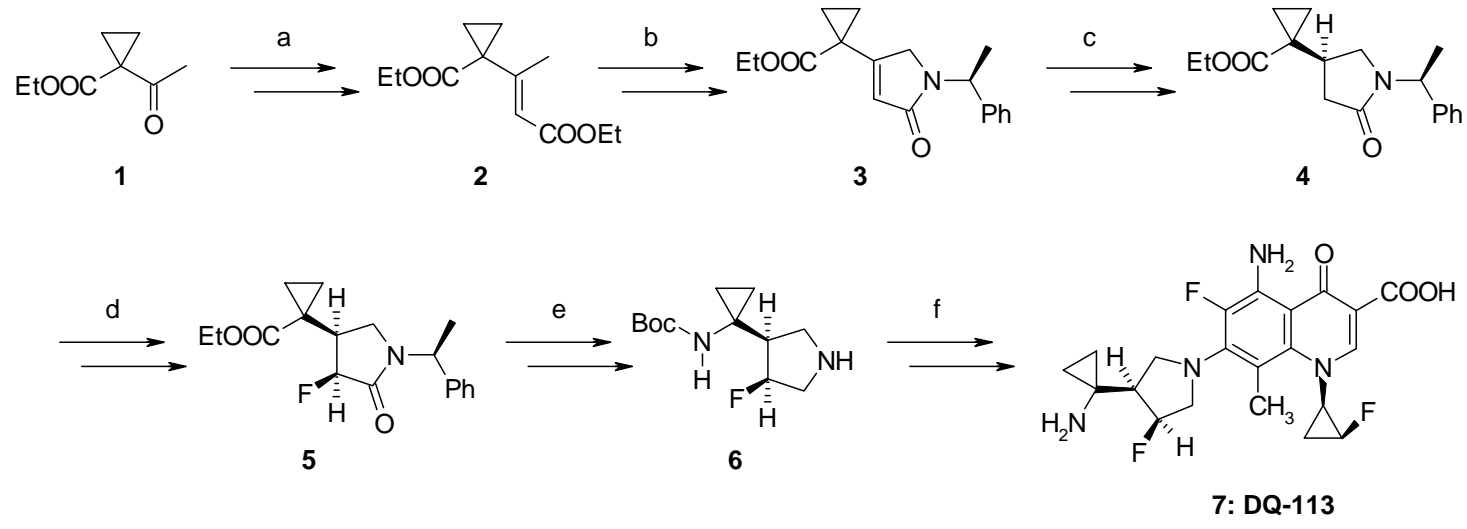

${ }^{a}$ Reactions: (a) Reformatsky reaction, elimination; (b) bromination, (S)-1-phenylethylamine, cyclization; (c) hydrogenation, separation of diastereomers; (d) fluorination, isomerization; (e) reduction, protecting group conversion, hydrolysis, Curtius rearrangement, deprotection; (f) aromatic nucleophilic substitution with 5-amino-6,7-difluoro-1-[(1R,2S)-2-fluorocycloprop-1yl]-1,4-dihydro-8-methyl-4-oxoquinoline-3-carboxylic acid, deprotection.

Scheme 1. ${ }^{a}$ The reported synthetic route for DQ-113 ${ }^{1}$

\section{Results and Discussion}

The new synthetic route for $\mathbf{6}$ is shown in Scheme 2. The Reformatsky reaction of 1acetylcyclopropanecarboxylate ${ }^{3} \mathbf{1}$ with bromofluoroacetate proceeded under standard conditions to give the fluoro-diester $\mathbf{8}$. The crude $\mathbf{8}$ was then treated with thionyl chloride/pyridine to give a chlorinated product. Treatment of the crude chlorinated product with 1,8diazabicyclo[5.4.0] undec-7-ene (DBU) gave the $\alpha$-fluoro- $\alpha, \beta$-unsaturated ester 9 as a 1:1 mixture of $(E)$ - and $(Z)$ - isomers in $79 \%$ yield from 1 . Bromination of the allylic position of the $E / Z$ mixture 9 with $\mathrm{N}$-bromosuccinimide (NBS) catalyzed by 2,2'-azo-bis-isobutyronitrile (AIBN) gave a 1.35:1 mixture of the $(E)$-bromo-diester $(E)-10$ and $(Z)$-bromo-diester $(Z)-10$ in $87 \%$ yield, which was separated to give the two isomers (silica gel column chromatography). The (Z)isomer $(Z)-10$, which could not be converted into the unsaturated lactam 11, could be converted into the mixture of $(\boldsymbol{E})-\mathbf{1 0}$ and $(Z)-10$ by heating with 0.1 eq. of NBS and 0.1 eq. of AIBN in benzene. After the isomerization process was repeated three times, the collected $(E)$-isomer $(E)$ 10 (83\% from 9) was treated with $(S)$-1-phenylethylamine and sodium hydrogencarbonate in ethanol to give the lactam 11 in $81 \%$ yield. Finally, hydrogenation of $\mathbf{1 1}$ catalyzed by Raney Nickel gave a $3: 1$ mixture of the $(3 S, 4 S)$-lactam 5 reported before, ${ }^{1}$ and the unwanted $(3 R, 4 R)$ lactam 12, in $86 \%$ yield, although other conditions using other catalysts lost face-selectivity 
and/or gave more des-fluorine products. The mixture of 5 and $\mathbf{1 2}$ could be separated easily into the two isomers by silica gel column chromatography. The $(3 S, 4 S)$-lactam 5 obtained by this route could be transformed into 6 in about the same yield as reported before. ${ }^{1}$

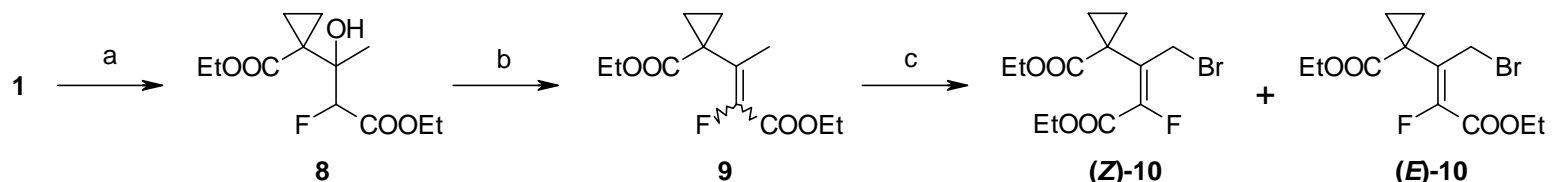

8

9

(Z)-10

(E)-10
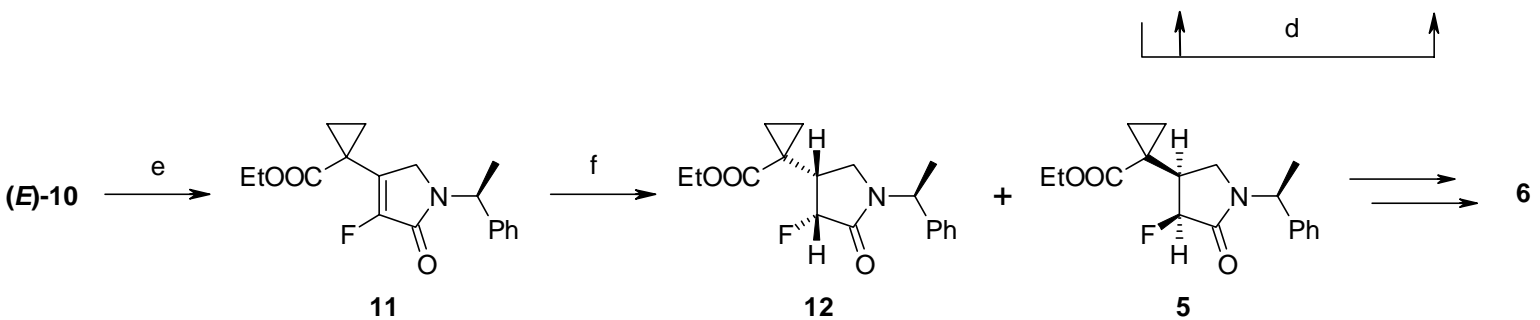

${ }^{a}$ Reagents: (a) $\mathrm{BrFCHCO}_{2} \mathrm{Et}$, Zn, cat. $\mathrm{I}_{2} /$ benzene; (b) $\mathrm{SOCl}_{2} /$ pyridine, then $\mathrm{DBU} / \mathrm{CH}_{2} \mathrm{Cl}_{2}(79 \%$ from 1); (c) NBS, cat. AIBN/benzene; (d) 0.1 eq. NBS, 0.1 eq. AIBN/benzene; (e) (S)-1-phenylethylamine, $\mathrm{NaHCO}_{3} / \mathrm{EtOH}$ (81\%, 67\% from 9); (f) $\mathrm{H}_{2}$, Raney Ni (W-6)/EtOH (12: 21\%; 5: 65\%).

Scheme 2. ${ }^{a}$ The new improved synthetic route for DQ-113 utilizing the Reformatsky reaction with bromofluoroacetate.

In order to avoid the chromatographic separation of $(Z)-10$ and $(E)-10$, and to obtain 11 more efficiently with shorter routes, we tried to develop two new synthetic routes for 11, shown in Scheme 3. The key step of one route $(\mathbf{1} \rightarrow \mathbf{1 3} \rightarrow \mathbf{1 4} \rightarrow \mathbf{1 5} \rightarrow \mathbf{1 6} \rightarrow \mathbf{1 1})$ is a Reformatsky reaction between the amino-ketone $\mathbf{1 4}$ and bromofluoroacetate, and of the other $(\mathbf{1} \rightarrow \mathbf{1 3} \rightarrow \mathbf{1 7} \rightarrow \mathbf{1 6} \rightarrow \mathbf{1 1})$ is the intramolecular Reformatsky reaction of $\mathbf{1 7}$. However, under standard conditions, both of the Reformatsky reactions gave complex mixtures and did not afford the key intermediates $\mathbf{1 5}$ or $\mathbf{1 6 .}$ Using other reaction conditions, it is possible that these new processes might be achieved in future.

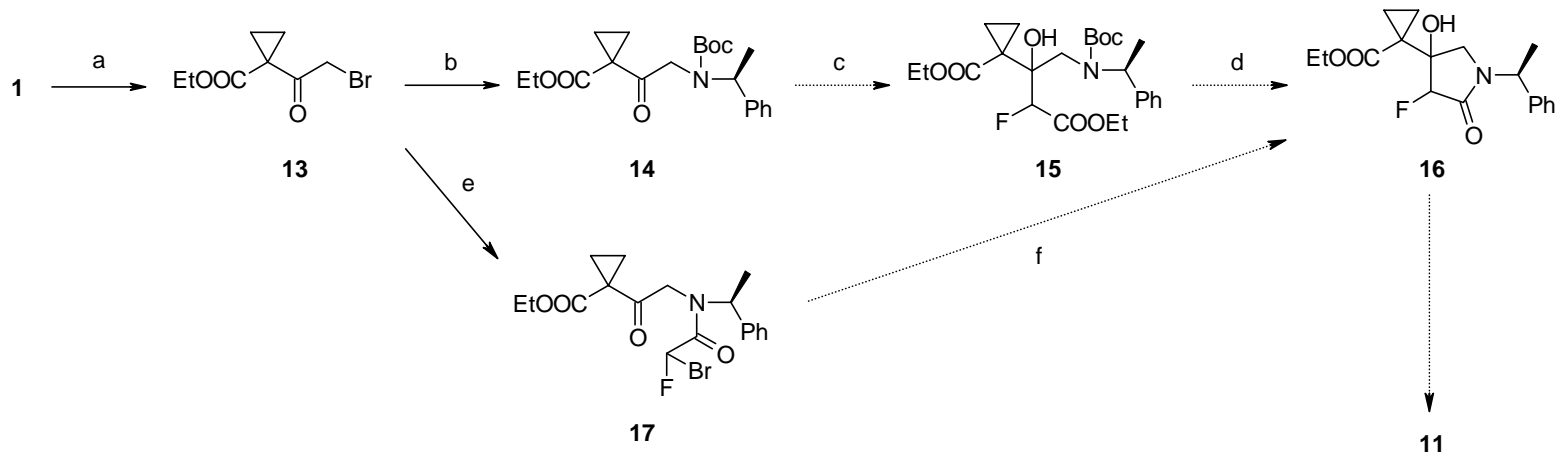

${ }^{a}$ Reagent or reaction: (a) Bromination; (b) (1) (S)-1-phenylethylamine; (2) $\mathrm{Boc}_{2} \mathrm{O}$; (c) Reformatsky reaction with $\mathrm{BrFCHCO}_{2} \mathrm{Et}$; (d) deprotection and cyclization; (e) (1) (S)-1-phenylethylamine; (2) $\mathrm{BrFCHCOCl}$; (f) intramolecular Reformatsky reaction. 
Scheme 3. ${ }^{a}$ Two possible (unachieved) synthetic routes for $\mathbf{1 1 .}$

\section{Conclusions}

Thus, we have developed a new synthetic route for $\mathbf{6}$ utilizing the Reformatsky reaction between the 1-acetylcyclopropanecarboxylate 1 and ethyl bromofluoroacetate. In this route, expensive fluorinating agents or operations at very low temperature were not needed. The total yield from $\mathbf{1}$ to 5 (6 steps, and 3 times isomerization process) was improved to $41 \%$, from the earlier quoted value of $10 \%$ ( 8 steps).

\section{Experimental Section}

General Procedures. Unless otherwise stated, materials were from commercial suppliers were used without further purification. Optical rotations were measured in a $0.5-\mathrm{dm}$ cell at $25^{\circ} \mathrm{C}$ at $589 \mathrm{~nm}$ with a HORIBA SEPA-300 polarimeter. ${ }^{1} \mathrm{H}$ NMR spectra were determined on a JEOL JNM-EX400 spectrometer. Chemical shifts are reported in ppm relative to tetramethylsilane as internal standard. Significant ${ }^{1} \mathrm{H}$ NMR data are tabulated in the order: number of protons, multiplicity (s, singlet; d, doublet; t, triplet; q; quartet; m, multiplet), coupling constant(s) in Hz. High-resolution mass spectra were obtained on a JEOL JMS-700 mass spectrometer under electron impact ionization (EI), electron spray ionization (ESI), or fast-atom bombardment conditions (FAB). Column chromatography refers to flash column chromatography using on Merck silica gel 60, 230-400 mesh ASTM. Thin-layer chromatography (TLC) was performed with Merck silica gel $60 \mathrm{~F}_{254}$ TLC plates, and compound visualization was effected with a 5\% solution of molybdophosphoric acid in ethanol, UV-lamp, iodine, or Wako Ninhydrin Spray.

Ethyl (E/Z)-3-(1-ethoxycarbonylcycloprop-1-yl)-2-fluoro-2-butenoate (9). To a solution of ethyl 1-acetylcyclopropanecarboxylate (1) (124.5 g, $0.797 \mathrm{~mol}$ ) in $1.5 \mathrm{~L}$ of $\mathrm{PhH}$ was added $\mathrm{Zn}$ powder (156.4 g, $2.393 \mathrm{~mol}$ ) and a catalytic amount of $\mathrm{I}_{2}$. To the mixture, heated under reflux, a solution of ethyl bromofluoroacetate $(94.2 \mathrm{ml}, 0.797 \mathrm{~mol})$ in $200 \mathrm{~mL}$ of $\mathrm{PhH}$ was added dropwise over $1 \mathrm{~h}$, and the mixture was heated under reflux for another $1 \mathrm{~h}$. The mixture was cooled on an ice bath, and $1 \mathrm{~L}$ of aqueous $1 \mathrm{M} \mathrm{HCl}$ solution was added. After stirring for $1 \mathrm{~h}$, the organic layer was separated. The organic solution was washed with aqueous $1 \mathrm{M} \mathrm{HCl}$ solution, water, brine, dried over $\mathrm{Na}_{2} \mathrm{SO}_{4}$, and concentrated in vacuo to give crude $\mathbf{8}$. To the crude 8 in pyridine $(387 \mathrm{~mL}, 4.78 \mathrm{~mol})$ was added thionyl chloride $(69.8 \mathrm{~mL}, 0.957 \mathrm{~mol})$ at $-10{ }^{\circ} \mathrm{C}$, and the mixture was stirred for $3 \mathrm{~h}$ at the same temperature. The resultant mixture was poured into $2 \mathrm{~L}$ of ice cold aqueous $1 \mathrm{M} \mathrm{HCl}$ solution, and was extracted with $1.5 \mathrm{~L}$ of AcOEt. The organic layer was washed with aqueous $1 \mathrm{M} \mathrm{HCl}$ solution, water, brine, dried over $\mathrm{Na}_{2} \mathrm{SO}_{4}$, and concentrated in vacuo to give the crude chlorinated product. To this, in $0.5 \mathrm{~L}$ of $\mathrm{CH}_{2} \mathrm{Cl}_{2}$, was added DBU $(131 \mathrm{~mL}, 0.877 \mathrm{~mol})$ at $0^{\circ} \mathrm{C}$, and the mixture was stirred for $17 \mathrm{~h}$ at ambient temperature. The reaction mixture was partitioned between $1 \mathrm{~L}$ of $\mathrm{CHCl}_{3}$ and $2 \mathrm{~L}$ of aqueous $1 \mathrm{M} \mathrm{HCl}$ solution, 
and the organic layer was washed with brine, dried over $\mathrm{Na}_{2} \mathrm{SO}_{4}$, and concentrated in vacuo to give crude 9. This was purified by silica gel chromatography, eluting with AcOEt:hexane $=1: 4$ to yield 9 as an $E / Z$ mixture $\left(152.8 \mathrm{~g}, 79 \%, E / Z=1 / 1\right.$, by $\left.{ }^{1} \mathrm{H} N M R\right)$ as a colorless oil. This $E / Z$ mixture was used for the next reaction without separation of isomers. ${ }^{1} \mathrm{H}$ NMR $\left(\mathrm{CDCl}_{3}\right) \delta 0.96-$ $0.98(0.5 \times 2 \mathrm{H}, \mathrm{m}), 1.04-1.07(0.5 \times 2 \mathrm{H}, \mathrm{m}), 1.20-1.38(6 \mathrm{H}, \mathrm{m}), 1.50-1.56(2 \mathrm{H}, \mathrm{m}), 1.93(0.5 \times$ $3 \mathrm{H}, J=4.9 \mathrm{~Hz}), 2.16(0.5 \times 3 \mathrm{H}, J=3.4 \mathrm{~Hz}), 4.10-4.16(2 \mathrm{H}, \mathrm{m}), 4.24-4.31(2 \mathrm{H}, \mathrm{m})$.

Ethyl (Z)-4-bromo-3-(1-ethoxycarbonylcycloprop-1-yl)-2-fluoro-2-butenoate $[(Z)-10]$ and ethyl (E)-4-bromo-3-(1-ethoxycarbonylcycloprop-1-yl)-2-fluoro-2-butenoate [(E)-10]. To a solution of ethyl (E/Z)-3-(1-ethoxycarbonylcycloprop-1-yl)-2-fluoro-2-butenoate (9) (152.8 g, $0.625 \mathrm{~mol})$ in $1.5 \mathrm{~L}_{\text {of }} \mathrm{CHCl}_{3}$ was added NBS $(111.3 \mathrm{~g}, 0.625 \mathrm{~mol})$ and a catalytic amount of AIBN, and the mixture was heated under reflux for $16 \mathrm{~h}$. After cooling to ambient temperature, the mixture was concentrated in vacuo. $0.3 \mathrm{~L}$ of benzene was added to the residue, and the resultant suspension was filtered. The filtrate was concentrated in vacuo, and the resultant crude product was separated into two isomers by silica gel chromatography. (E)-10 (100.5 g, 50\%) was obtained as a pale yellow oil, eluting with AcOEt:hexane $=1: 4 .{ }^{1} \mathrm{H} \mathrm{NMR}\left(\mathrm{CDCl}_{3}\right) \delta 1.23(3 \mathrm{H}, \mathrm{t}$, $J=7.1 \mathrm{~Hz}), 1.38(3 \mathrm{H}, \mathrm{t}, J=7.1 \mathrm{~Hz}), 1.52-1.62(4 \mathrm{H}, \mathrm{m}), 4.11(2 \mathrm{H}, \mathrm{q}, J=7.1 \mathrm{~Hz}), 4.35(2 \mathrm{H}, \mathrm{q}, J$ $=7.1 \mathrm{~Hz}), 4.54(2 \mathrm{H}, \mathrm{s})$. High-resolution MS (FAB) Calcd. for $\mathrm{C}_{12} \mathrm{H}_{17} \mathrm{O}_{4} \mathrm{~F}^{79} \mathrm{Br}+\mathrm{H}$ : 323.0294 . Found: 323.0261. Calcd. for $\mathrm{C}_{12} \mathrm{H}_{17} \mathrm{O}_{4} \mathrm{~F}^{81} \mathrm{Br}+\mathrm{H}$ : 325.0275. Found: 325.0273. Further elution with AcOEt:hexane $=1: 2$ afforded $(Z)-10(75.0 \mathrm{~g}, 37 \%)$ as a pale yellow oil. ${ }^{1} \mathrm{H} \mathrm{NMR}\left(\mathrm{CDCl}_{3}\right) \delta$ $1.21(3 \mathrm{H}, \mathrm{t}, J=7.1 \mathrm{~Hz}), 1.32(3 \mathrm{H}, \mathrm{t}, J=7.1 \mathrm{~Hz}), 1.52-1.62(4 \mathrm{H}, \mathrm{m}), 4.11(2 \mathrm{H}, \mathrm{q}, J=7.1 \mathrm{~Hz})$, $4.13(2 \mathrm{H}, \mathrm{s}), 4.29(2 \mathrm{H}, \mathrm{q}, J=7.1 \mathrm{~Hz})$. High-resolution MS (FAB) Calcd. for $\mathrm{C}_{12} \mathrm{H}_{17} \mathrm{O}_{4} \mathrm{~F}^{79} \mathrm{Br}+\mathrm{H}$ : 323.0294. Found: 323.0309. Calcd. for $\mathrm{C}_{12} \mathrm{H}_{17} \mathrm{O}_{4} \mathrm{~F}^{81} \mathrm{Br}+\mathrm{H}$ : 325.0275 . Found: 325.0296 .

Isomerization of $(Z)-10$ to a mixture of $(Z)-10$ and $(E)-10$. A mixture of ethyl (Z)-4-bromo-3(1-ethoxycarbonylcycloprop-1-yl)-2-fluoro-2-butenoate (Z)-10, 0.1 eq. of NBS, and 0.1 eq. of AIBN was dissolved in benzene, and heated under reflux under nitrogen for $12-16 \mathrm{~h}$. After the solvent was evaporated, the remaining residue was purified and separated by silica gel chromatography, eluting with AcOEt:hexane $=1: 20 \rightarrow 1: 10 \rightarrow 1: 4 \rightarrow 1: 2$ to give $(\boldsymbol{E})-\mathbf{1 0}$ and a mixture of $(E)-10$ and $(Z)-10$. Using the mixture of $(E)-10$ and $(Z)-10$, the same isomerization procedure was repeated three times to give total 89\% of $(\boldsymbol{E})-\mathbf{1 0}$ from $(Z)-10$.

Ethyl 1-\{4-fluoro-2,5-dihydro-5-oxo-1-[(S)-1-phenylethyl]-1H-pyrrol-3-yl\}cyclopropanecarboxyl-ate (11). To a solution of ethyl (E)-4-bromo-3-(1-ethoxycarbonylcycloprop-1-yl)-2fluoro-2-butenoate $[(\boldsymbol{E})-\mathbf{1 0}](46.2 \mathrm{~g}, 0.143 \mathrm{~mol})$ in $1 \mathrm{~L}$ of $\mathrm{EtOH}$ was added $\mathrm{NaHCO}_{3}(30.1 \mathrm{~g}$, $0.358 \mathrm{~mol})$, and then $(S)-1$-phenylethylamine $(20.3 \mathrm{~mL}, 0.158 \mathrm{~mol})$, dropwise at ambient temperature. After heating under reflux for $3 \mathrm{~h}$, the mixture was cooled to ambient temperature and filtered through Celite. The filtrate was concentrated in vacuo, and purified by silica gel chromatography, eluting with AcOEt:hexane =1:2 to yield 11 (37.0 g, 81\%) as a colorless oil. ${ }^{1} \mathrm{H}$ NMR $\left(\mathrm{CDCl}_{3}\right): \delta 1.16(3 \mathrm{H}, \mathrm{t}, J=7.1 \mathrm{~Hz}), 1.22-1.30(2 \mathrm{H}, \mathrm{m}), 1.55-1.59(2 \mathrm{H}, \mathrm{m}), 1.62(3 \mathrm{H}, \mathrm{d}$, $J=7.3 \mathrm{~Hz}), 3.60(1 \mathrm{H}, \mathrm{dd}, J=18.1,5.4 \mathrm{~Hz}), 3.92(1 \mathrm{H}, \mathrm{dd}, J=18.1,5.4 \mathrm{~Hz}), 4.08(2 \mathrm{H}, \mathrm{q}, J=7.1$ $\mathrm{Hz}), 5.56(1 \mathrm{H}, \mathrm{q}, J=7.3 \mathrm{~Hz}), 7.25-7.37(5 \mathrm{H}, \mathrm{m})$. High-resolution MS (EI) Calcd. for $\mathrm{C}_{18} \mathrm{H}_{20} \mathrm{NO}_{3} \mathrm{~F}: 317.1427$. Found: 317.1414 . $[\alpha]_{\mathrm{D}}-37.9^{\circ}$ (c 1.594, $\mathrm{CHCl}_{3}$ ). 
Ethyl 1-\{(3R,4R)-4-fluoro-5-oxo-1-[(S)-1-phenylethyl]pyrrolidin-3-yl\}cyclopropane-carboxylate (12) and ethyl 1-\{(3S,4S)-4-fluoro-5-oxo-1-[(S)-1-phenylethyl]pyrrolidin-3-yl\}-cyclopropane-carboxylate (5). To a solution of ethyl 1-\{4-fluoro-2,5-dihydro-5-oxo-1-[(S)-1-phenylethyl]-1H-pyrrol-3yl cyclopropane-carboxylate (11) $(587 \mathrm{mg}, 1.85 \mathrm{mmol})$ in $5 \mathrm{~mL}$ of EtOH was added Raney Nickel (W-6) (2 mL), and the mixture was stirred vigorously under $5 \mathrm{~kg} / \mathrm{cm}^{2}$ of hydrogen atmosphere at ambient temperature for $1 \mathrm{~h}$. After more Raney Nickel (W-6) (3 mL) was added to the mixture, the mixture was reacted $2.5 \mathrm{~h}$ further under the conditions mentioned above. The resultant mixture was filtered (Celite), and the filtrate was concentrated in vacuo. The residue was separated into two isomers by silica gel chromatography; 5 (382 mg, 65\%) was obtained as a colorless oil, eluting with AcOEt:hexane $=1: 3$. The spectroscopic data of 5 were identical to those reported. ${ }^{1}$ Compound $12(101 \mathrm{mg}, 21 \%)$ was obtained as a colorless oil, eluting with AcOEt:hexane = 1:3. ${ }^{1} \mathrm{H}$ NMR $\left(\mathrm{CDCl}_{3}\right) \delta$ 0.66-0.71 $(1 \mathrm{H}, \mathrm{m}), 0.97-1.02(1 \mathrm{H}, \mathrm{m}), 1.25-1.35(1 \mathrm{H}$, $\mathrm{m}), 1.22(3 \mathrm{H}, \mathrm{t}, J=7.2 \mathrm{~Hz}), 1.19-1.26(1 \mathrm{H}, \mathrm{m}), 1.32-1.36(1 \mathrm{H}, \mathrm{m}), 1.57(3 \mathrm{H}, \mathrm{d}, J=7.1 \mathrm{~Hz})$, 2.76-2.88 (1H, m), 2.92-3.03 (2H, m), $4.12(2 \mathrm{H}, \mathrm{q}, J=7.2 \mathrm{~Hz}), 5.15(1 \mathrm{H}, \mathrm{dd}, J=52.7,6.3 \mathrm{~Hz})$, $5.53(1 \mathrm{H}, \mathrm{q}, J=7.0 \mathrm{~Hz}), 7.27-7.37(5 \mathrm{H}, \mathrm{m})$. High-resolution MS (EI) Calcd. for $\mathrm{C}_{18} \mathrm{H}_{22} \mathrm{NO}_{3} \mathrm{~F}$ : 319.1584. Found: $319.1585,[\alpha]_{\mathrm{D}}-31.4^{\circ}\left(c 0.793, \mathrm{CHCl}_{3}\right)$.

\section{References}

1. Inagaki, H.; Miyauchi, S.; Miyauchi, R. N.; Kawato, H. C.; Ohki, H; Matsuhashi, N.; Kawakami, K.; Takahashi, H.; Takemura, M. J. Med. Chem. 2003, 46, 1005.

2. Tanaka, M.; Yamazaki, E.; Chiba, M.; Yoshihara, K.; Akasaka, T.; Takemura, M.; Sato, K. Antimicrob. Agents Chemother. 2002, 46, 904.

3. Matsumoto, T.; Shirahama, H.; Ichihara, A.; Shin, H.; Kagawa, S.; Hisamitsu, T.; Kamada, T.; Sakan, F. Bull. Chem. Soc. Japan 1972, 45, 1136. 